\title{
Chemical characterisation of meltwater draining from Gangotri Glacier, Garhwal Himalaya, India
}

\author{
Virendra Bahadur Singh, Al Ramanathan*, Jose George Pottakkal, \\ Parmanand Sharma, Anurag Linda, Mohd Faroog Azam and C Chatterjee \\ School of Environmental Sciences, Jawaharlal Nehru University, New Delhi 110 067, India. \\ *Corresponding author.e-mail: alrjnu@gmail.com virendrasinghjnu@gmail.com
}

A detailed analytical study of major cations $\left(\mathrm{Ca}^{2+}, \mathrm{Mg}^{2+}, \mathrm{Na}^{+}, \mathrm{K}^{+}\right)$and anions $\left(\mathrm{SO}_{4}^{2-}, \mathrm{HCO}_{3}^{-}, \mathrm{Cl}^{-}\right.$, $\mathrm{NO}_{3}^{-}$) of meltwater draining from Gangotri Glacier was carried out to understand major ion chemistry and to get an insight into geochemical weathering processes controlling hydrochemistry of the glacier. In the meltwater, the abundance order of cations and anions varied as follows: $\mathrm{Ca}^{2+}>\mathrm{Mg}^{2+}>\mathrm{K}^{+}>$ $\mathrm{Na}^{+}$and $\mathrm{SO}_{4}^{2-}>\mathrm{HCO}_{3}^{-}>\mathrm{Cl}^{-}>\mathrm{NO}_{3}^{-}$, respectively. Calcium and magnesium are dominant cations while sulphate and bicarbonate are dominant anions. Weathering of rocks is the dominant mechanism controlling the hydrochemistry of drainage basin. The relative high contribution of $(\mathrm{Ca}+\mathrm{Mg})$ to the total cations $\left(\mathrm{TZ}^{+}\right)$, high $(\mathrm{Ca}+\mathrm{Mg}) /(\mathrm{Na}+\mathrm{K})$ ratio $(2.63)$ and low $(\mathrm{Na}+\mathrm{K}) / \mathrm{TZ}^{+}$ratio $(0.29)$ indicate the dominance of carbonate weathering as a major source for dissolved ions in the glacier meltwater. Sulphide oxidation and carbonation are the main proton supplying geochemical reactions controlling the rock weathering in the study area. Statistical analysis was done to identify various factors controlling the dissolved ionic strength of Gangotri Glacier meltwater.

\section{Introduction}

Glacierised areas present an ideal environment to study water-rock interaction, since chemical weathering rates are high and anthropogenic impacts are often minimal (Brown 2002). The Indian Himalayan region $\left(27^{\circ}-36^{\circ} \mathrm{N}\right.$ and $72^{\circ}$ $96^{\circ} \mathrm{E}$ ) consists a total of 9575 glaciers (Raina and Srivastava 2008) covering an area of about $40,000 \mathrm{~km}^{2}$. All three major river systems of north India, the Ganga, Brahmaputra and Indus originate from the Himalayan snow and ice fields. Himalaya is considered a geodynamically active area and is prone to violent crustal movements, which are responsible for seismicity and high erosion rates (Valdiya 1998). The growing demand for freshwater in downstream stretches and the geolo- gical setting has made the hydrochemical study of Himalayan glaciers highly imperative.

Solute in the meltwater is derived during the passage of meltwater through the sub-glacier channel at the rock-ice and meltwater interface (Trudgill 1986). The rate and mechanism responsible for dissolved ion release in the meltwater of glacier streams vary with lithology (Collins 1979a). Weathering of bedrock is likely to occur when water flows at the ice-rock interface. In glacial environment, proton $\left(\mathrm{H}^{+}\right)$appears to be accountable for the weathering of rock-forming minerals. The carbon dioxide reacts with water and form the weak carbonic acid, which dissociates into $\mathrm{H}^{+}$ and $\mathrm{HCO}_{3}^{-}$. Sulphide oxidation is another mechanism, which is responsible for the production of hydrogen ions (Garrels and Mackenzie 1971). The

Keywords. Hydrochemistry; weathering; Gangotri Glacier; Himalaya. 
hydrogen ions produced react with carbonate, silicate or aluminosilicate minerals, which result in release of cations, dissolved silica and clay minerals (Raiswell 1984).

Various studies on Alpine glaciers by Rainwater and Guy (1961); Beherens et al (1971); Lorrain and Souchez (1972); Collins (1978, 1979a, 1979b); Tranter and Raiswell (1991) and in Himalayan region by Singh et al (1998) and Ahmad and Hasnain (2001) have suggested two principal flow components, viz., water passing through subglacial channels in contact with the rock substrate and water running off rapidly through englacial channels without undergoing significant chemical change. These studies indicate the high rate of chemical weathering in glaciated regions resulting from long residence times of meltwater in contact with the bed rock. There are a few studies that deal with Gangotri Glacier meltwater such as Ahmad and Hasnain (2000) and Kumar et al (2009). But only very few studies including that of Trivedi et al (2010) discuss in detail the hydrochemical variability of the meltwater of the Gangotri Glacier. This particular study has been carried out in view of the lacunae in existing knowledge to give an insight into the chemical characteristics of meltwater and the factors controlling geochemical weathering processes operating in Gangotri Glacier.

\section{Study area}

The Gangotri Glacier located in the Uttarkashi district of Uttarakhand state is one of the largest Himalayan glaciers. This glacier is bound between $30^{\circ} 43^{\prime} 22^{\prime \prime}-30^{\circ} 55^{\prime} 49^{\prime \prime}$ (lat.) and $79^{\circ} 4^{\prime} 41^{\prime \prime}-79^{\circ} 16^{\prime} 34^{\prime \prime}$ (long.) and is classified as valley-type glacier (Naithani et al 2001). The Bhagirathi River originates from Gaumukh (meaning 'mouth of cow'), the snout of the Gangotri Glacier. It is located at an elevation of about 4000 m.a.s.l. Although it is commonly known as Gangotri Glacier, in fact it is Gangotri Glacier System consisting of a cluster of many small and large glaciers. This system comprises three major glacier tributaries, namely, Kirti Glacier (length $11.05 \mathrm{~km}$; area $33.14 \mathrm{~km}^{2}$ ), Raktvarn Glacier (length $15.90 \mathrm{~km}$; area $55.30 \mathrm{~km}^{2}$ ) and Chaturangi Glacier (length $22.45 \mathrm{~km}$; area $67.70 \mathrm{~km}^{2}$ ) with main Gangotri Glacier (length $30.20 \mathrm{~km}$; area $86.32 \mathrm{~km}^{2}$ ) as the trunk part of the system (Singh et al 2011). Beside these three major glaciers, some other tributary glaciers of this area are directly draining into Gangotri Glacier; among them Swachand, Miandi, Sumeru and Ghanohim are important. Four other glaciers, which directly drain into the Bhagirathi River are Maitri, Meru, Bhrigupanth and Manda and the total glacierized area of the catchment is $258.56 \mathrm{~km}^{2}$ (Naithani et al 2001). The sampling site was located about $1.5 \mathrm{~km}$

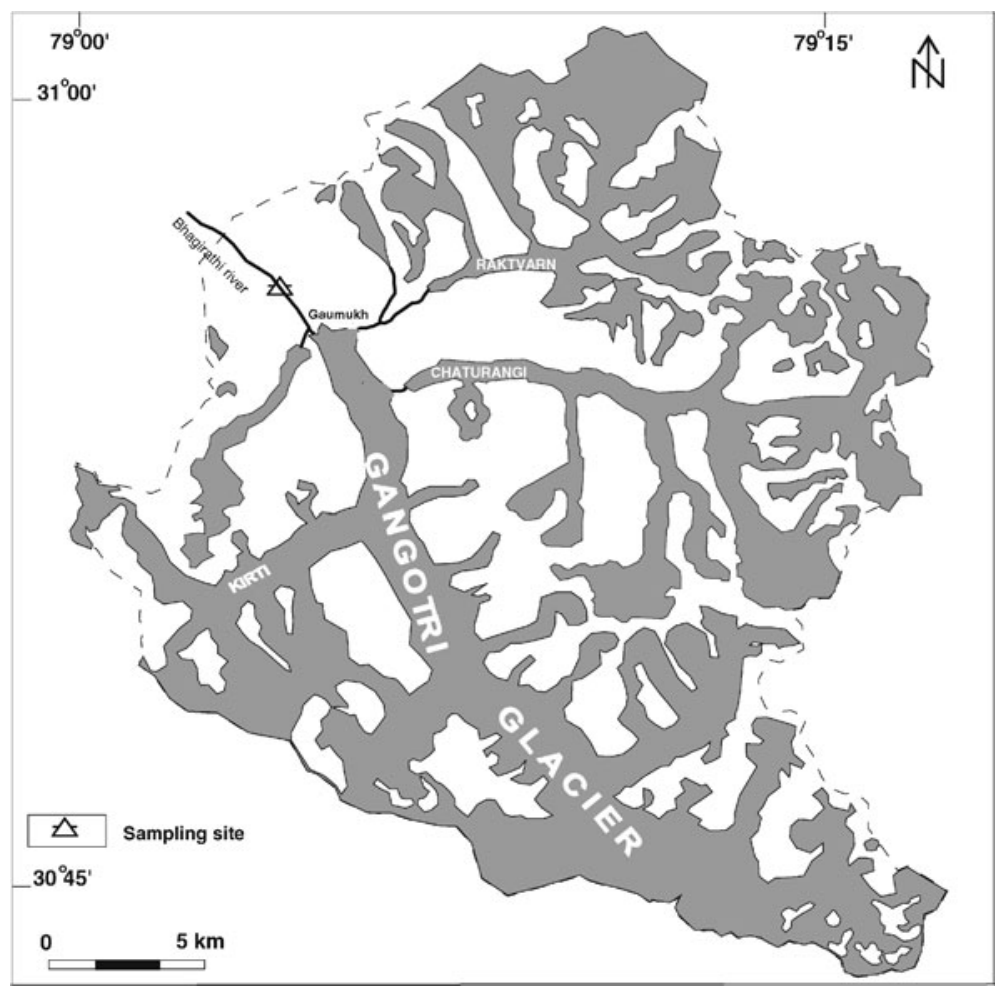

Figure 1. Map of the study area showing location of sampling site (modified after Singh et al 2011). 
downstream from the snout of Gangotri Glacier at an elevation of about 3900 m.a.s.l (figure 1).

Geologically, the Gangotri Glacier System falls in the Central Crystalline Zone. From Gangotri further northeast, the mica schist, which is the dominant rock type above the Main Central Thrust (MCT) is retrograded in chlorite schist and intruded by hard and massive granite (Gangotri granite) (Kumar et al 2009). The Gangotri granite is one of the largest bodies of the Higher Himalayan Leucogranite belt located in the Garhwal Himalaya (Heim and Gansser 1939; Gansser 1964; Le Fort 1975; Yin 2006). It is exposed around the Gangotri Glacier region along the upper reaches of Bhagirathi River, including the peaks of Thalay Sagar (6904 m), Meru (6672 m), Shivling (6543 m), Bhagirathi $(6856 \mathrm{~m})$ and Bhrigupanth $(6044 \mathrm{~m})$ (Jowhar 2010). The Gangotri granite is fine grained (1-2 mm), composed of quartz + K-feldspar + plagioclase + tourmaline + muscovite \pm biotite (present only in the biotite-rich facies), \pm garnet (present only in the tourmaline-rich facies), \pm beryl, with apatite as the most abundant accessory mineral (Scaillet et al 1990; Jowhar 2010).

Granitic rocks of the Gangotri-Gaumukh area form a part of the Badrinath granitoid that has intrusive contact with the overlying and underlying metasedimentary rocks (Bassi 2004). However, detailed field investigations along the Gangotri Glacier and around the peaks of Bhagirathi, Meru, Shivling and Thalay Sagar have shown that regional, Barrovian facies metamorphic rocks underlie each leucogranite outlier (Searle et al 1999). Both $\mathrm{CaSO}_{4}$ and $\mathrm{MgSO}_{4}$ are found in Gaumukh-Gangotri shrine section. Sulphate minerals are normally expected to be associated with carbonate rocks, which are likely to have same packets, particularly when evaporites, such as, gypsum and anhydrite are present (Srivastava et al 2004). Several sulphide minerals like pyrite, chalcopyrite and arsenopyrites at the contact of quartz veinlets which traverses the country rocks are reported near the source area of Bhagirathi River (Bhatt 1963).

\section{Materials and methods}

Meltwater samples $(n=52)$ draining from Gangotri Glacier were collected during the period from July to September 2007. The samples were collected two times a day, corresponding to diurnal low flow $(0800 \mathrm{~h})$ and high flow $(1800 \mathrm{~h})$. The samples were collected in prewashed polyethylene bottles of $300 \mathrm{ml}$ capacity. Before collecting the samples, bottles were rinsed with the meltwater at the sampling site. The sample collection was done following the method suggested by Ostrem (1975).
Separate aliquots of the samples were removed to measure the electrical conductivity (EC) and $\mathrm{pH}$ in the field by using portable multiparameter meter (HACH-Sension 156). Bicarbonate was determined at the sampling site by acid titration method (APHA 2005). The samples were filtered through $0.45 \mu \mathrm{m}$ Millipore membrane filters immediately after reaching the laboratory using vacuum filtration setup and stored at about $3^{\circ} \mathrm{C}$ during the period of analysis.

Dissolved silica analysis was carried out by molybdosilicate method (APHA 2005). Chloride concentration was determined by mercury (II) thiocyanate method (Florence and Farrar 1971). The turbidimetric method and brucine-sulphanilic acid method (APHA 2005) were used to measure the concentrations of sulphate and nitrate respectively. Major cations $\left(\mathrm{Ca}^{2+}, \mathrm{Mg}^{2+}, \mathrm{Na}^{+}\right.$and $\mathrm{K}^{+}$) were analysed by atomic absorption spectrophotometer (Shimadzu-AA-6800). $\mathrm{Ca}^{2+}$ and $\mathrm{Mg}^{2+}$ were determined in the absorbance mode and $\mathrm{Na}^{+}$ and $\mathrm{K}^{+}$in the emission mode. The analytical precision for the measurement of major ions was better than $\pm 5 \%$. TDS was calculated by summation of the masses of all the major dissolved constituents measured in each sample. Aquachem software was used for plotting the Piper diagram. Factor analysis for meltwater samples of the study area was carried out by Statistical Package for Social Sciences (SPSS); version - 10.5. Varimax rotation and principal component analysis were used for factor deriving and extraction respectively.

\section{Results and discussion}

\subsection{Hydrochemistry}

Chemical characteristics of meltwater draining from Gangotri Glacier is given in table 1. The charge balance errors determined by the formula $\left(\mathrm{TZ}^{+}-\mathrm{TZ}^{-} / \mathrm{TZ}^{+}+\mathrm{TZ}^{-} \times 100\right)$ were $<10 \%$ and the ratio of TDS/EC was $0.63 \pm 0.13$, confirming the reliability and quality of the analytical results. The average EC and $\mathrm{pH}$ values of meltwater of Gangotri Glacier were $81 \pm 5 \mu \mathrm{s} / \mathrm{cm}(69-$ $92 \mu \mathrm{s} / \mathrm{cm})$ and $7.2 \pm 0.3(6.2-7.7)$, respectively. These values are comparable to those reported in other available studies (Pandey et al 1999; Ahmad and Hasnain 2000) from the region. Sulphate was the dominant anion accounting $59.0 \%$ of the total anions. The average $\mathrm{SO}_{4}^{2-}$ concentration was $401 \pm 186 \mu \mathrm{eq} / \mathrm{l}(200-768 \mu \mathrm{eq} / \mathrm{l})$ followed by $\mathrm{HCO}_{3}^{-} 266 \pm 27 \mu \mathrm{eq} / \mathrm{l}(210-314 \mu \mathrm{eq} / \mathrm{l})$, $\mathrm{Cl}^{-} 11.2 \pm 11.0 \mu \mathrm{eq} / \mathrm{l}(1.4-66.2 \mu \mathrm{eq} / \mathrm{l})$ and $\mathrm{NO}_{3}^{-}$ $1.9 \pm 1.0 \mu \mathrm{eq} / \mathrm{l}(0.0-3.2 \mu \mathrm{eq} / \mathrm{l})$, respectively. In anionic abundance $\mathrm{SO}_{4}^{2-}$ was followed by $\mathrm{HCO}_{3}^{-}$, $\mathrm{Cl}^{-}$and $\mathrm{NO}_{3}^{-}$accounting $39.1 \%, 1.6 \%$ and $0.3 \%$ 
Table 1. Chemical characteristics of Gangotri Glacier meltwater.

\begin{tabular}{|c|c|c|c|c|}
\hline Parameter & $\operatorname{Max}$ & Min & Average & $\mathrm{SD}$ \\
\hline $\mathrm{EC}$ & 92 & 69 & 81 & 5 \\
\hline $\mathrm{pH}$ & 7.7 & 6.2 & 7.2 & 0.3 \\
\hline $\mathrm{Ca}^{2+}$ & 343 & 102 & 206 & 76 \\
\hline $\mathrm{Mg}^{2+}$ & 318 & 91 & 197 & 61 \\
\hline $\mathrm{K}^{+}$ & 126 & 42 & 83 & 16 \\
\hline $\mathrm{Na}^{+}$ & 128 & 45 & 75 & 16 \\
\hline $\mathrm{SO}_{4}^{2-}$ & 768 & 200 & 401 & 186 \\
\hline $\mathrm{HCO}_{3}^{-}$ & 314 & 210 & 266 & 27 \\
\hline $\mathrm{Cl}^{-}$ & 66.2 & 1.4 & 11.2 & 11.0 \\
\hline $\mathrm{NO}_{3}^{-}$ & 3.2 & 0.0 & 1.9 & 1.0 \\
\hline $\mathrm{H}_{4} \mathrm{SiO}_{4}$ & 139 & 21 & 64 & 23 \\
\hline $\mathrm{TZ}^{+}$ & 844 & 377 & 561 & 139 \\
\hline $\mathrm{TZ}^{-}$ & 1020 & 459 & 681 & 174 \\
\hline TDS & 73 & 35 & 51 & 12 \\
\hline$(\mathrm{Ca}+\mathrm{Mg}) / \mathrm{TZ}^{+}$ & 0.83 & 0.53 & 0.71 & 0.08 \\
\hline$(\mathrm{Na}+\mathrm{K}) / \mathrm{TZ}^{+}$ & 0.47 & 0.17 & 0.29 & 0.08 \\
\hline$(\mathrm{Ca}+\mathrm{Mg}) /(\mathrm{Na}+\mathrm{K})$ & 4.99 & 1.14 & 2.63 & 0.95 \\
\hline $\mathrm{Ca} / \mathrm{Na}$ & 5.33 & 1.06 & 2.85 & 1.15 \\
\hline $\mathrm{Mg} / \mathrm{Na}$ & 5.37 & 1.00 & 2.76 & 1.01 \\
\hline $\mathrm{HCO}_{3} / \mathrm{Na}$ & 6.53 & 1.91 & 3.73 & 0.94 \\
\hline $\mathrm{Na} / \mathrm{Cl}$ & 54.1 & 1.2 & 13.5 & 11.2 \\
\hline $\mathrm{K} / \mathrm{Cl}$ & 61.3 & 1.5 & 14.9 & 12.7 \\
\hline TDS/EC & 0.88 & 0.44 & 0.63 & 0.13 \\
\hline $\mathrm{C}$ ratio & 0.61 & 0.23 & 0.43 & 0.13 \\
\hline
\end{tabular}

Unit: Dissolved ions, $\mathrm{TZ}^{+}$; $\mathrm{TZ}^{-}$in $\mu \mathrm{eq} / \mathrm{l}$; TDS in $\mathrm{mg} / \mathrm{l}$; EC in $\mu \mathrm{s} / \mathrm{cm}$ and $\mathrm{H}_{4} \mathrm{SiO}_{4}$ in $\mu$ mole/l.

of total anions, respectively. The average $\mathrm{Ca}^{2+}$ concentration was found to be $206 \pm 76 \mu \mathrm{eq} / \mathrm{l}$ (102-343 $\mu \mathrm{eq} / \mathrm{l})$ followed by $\mathrm{Mg}^{2+} 197 \pm 61 \mu \mathrm{eq} / \mathrm{l}$

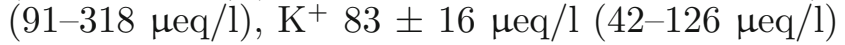
and $\mathrm{Na}^{+} 75 \pm 16 \mu \mathrm{eq} / \mathrm{l}(45-128 \mu \mathrm{eq} / \mathrm{l})$. The cation chemistry indicates that $\mathrm{Ca}^{2+}$ and $\mathrm{Mg}^{2+}$ were the dominant cations, on an average constituting $36.7 \%$ and $35.1 \%$ of the total cations respec- tively, followed by $\mathrm{K}^{+}(14.8 \%)$ and $\mathrm{Na}^{+}(13.3 \%)$. The average dissolved silica concentration in the Gangotri Glacier meltwater was recorded as $64 \pm$ $23 \mu \mathrm{mole} / \mathrm{l}(21-139 \mu \mathrm{mole} / \mathrm{l})$.

\subsection{Sources of dissolved ions}

The chemical composition of glacier meltwater demonstrates that chemical weathering takes place beneath the glacier (Reynolds and Johnson 1972; Raiswell 1984). The release of dissolved ions to the glacier streams is governed by the rock-water interaction, bed rock mineralogy, weathering reactions, composition of atmospheric deposition and rate of water flow in the glacier catchment (Singh and Hasnain 1998). The hydrochemistry of reservoir is likely to be determined by mixing of two components from dissolution of carbonates and silicates and the relative significance of these two sources can be explained by cationic abundance and their ratios (Singh et al 2005). The scatter plot of $(\mathrm{Ca}+\mathrm{Mg})$ vs. $\mathrm{TZ}^{+}$(figure $2 \mathrm{a}$ ) shows that most of the points fall above 1:1 equiline with an average equivalent ratio of $0.71 \pm 0.08$. The relatively high contribution of $(\mathrm{Ca}+\mathrm{Mg})$ to the total cations $\left(\mathrm{TZ}^{+}\right)$and high $(\mathrm{Ca}+\mathrm{Mg}) /(\mathrm{Na}+\mathrm{K})$ ratio $(2.63 \pm 0.95)$ indicate that carbonate weathering is a major source of dissolved ions in the meltwater of Gangotri Glacier, as reported by earlier researchers (Singh and Hasnain 1998; Pandey et al 1999; Kumar et al 2009). The scatter plot of $\mathrm{Na}+\mathrm{K} / \mathrm{TZ}^{+}$(figure $2 \mathrm{~b}$ ) shows that all points fall above $1: 1$ equiline with a low ratio $(0.29 \pm 0.08)$, indicating a relatively low contribution of dissolved ions from silicate weathering, also reported by other researchers (Singh and Hasnain 2002; Kumar et al 2009). $\mathrm{Na}^{+}, \mathrm{K}^{+}$and dissolved silica in the drainage basin are mainly derived from the weathering of silicate minerals, with clay minerals as

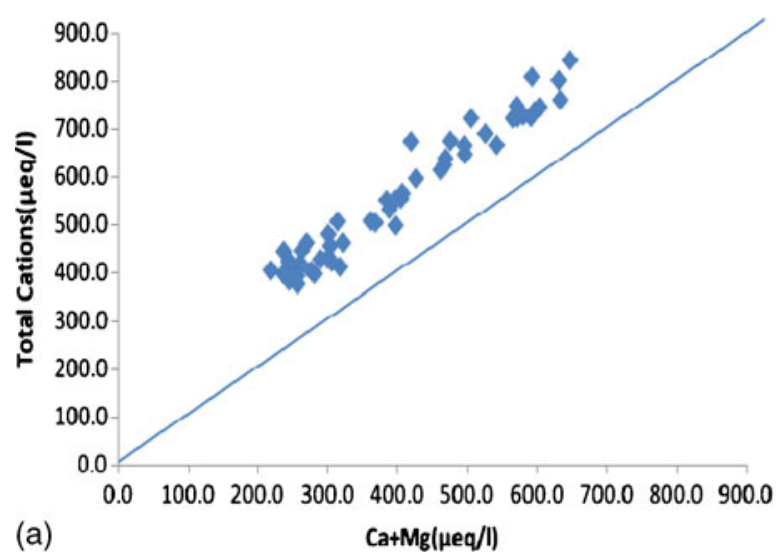

Figure 2. (a) Scatter plot between $\mathrm{Ca}+\mathrm{Mg}$ and total cations $\left(\mathrm{TZ}^{+}\right)$. (b) Scatter plot between $\mathrm{Na}+\mathrm{K}$ and total cations

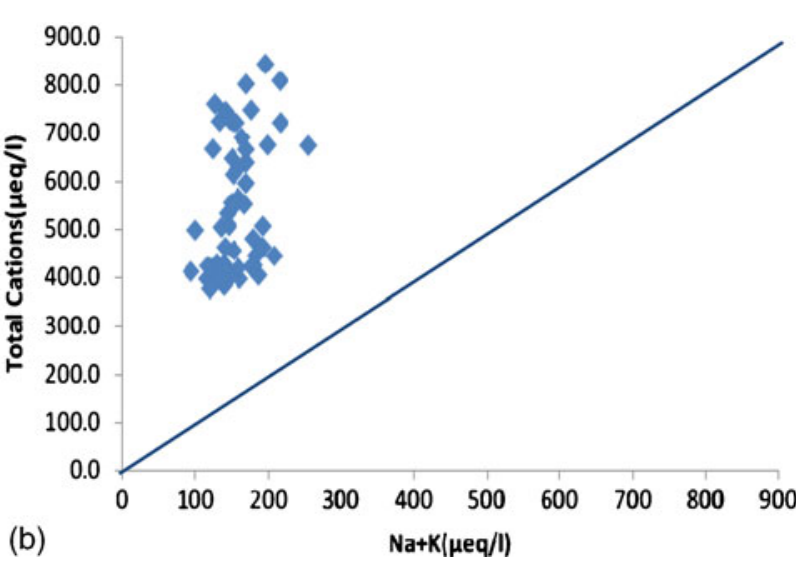

(b) $\left(\mathrm{TZ}^{+}\right)$. 
by-products. In the Ganga headwater, $\mathrm{Na}^{+}$and $\mathrm{K}^{+}$are mainly derived from igneous and metamorphic rocks of the Central Crystalline rocks. Micas, orthoclase $\left(\mathrm{KAlSi}_{3} \mathrm{O}_{8}\right)$ and albite are common parental minerals for $\mathrm{Na}^{+}$and $\mathrm{K}^{+}$release in the Ganga headwater, which may react with water and carbonic acid and accumulate clay minerals in the sediments (Singh and Hasnain 2002).

Water draining carbonates show $\mathrm{Ca}^{2+}$ and $\mathrm{Mg}^{2+}$ dominated reservoirs and $\mathrm{Ca} / \mathrm{Na}$ ratios close to $50, \mathrm{Mg} / \mathrm{Na}$ ratios close to 10 and $\mathrm{HCO}_{3} / \mathrm{Na}$ ratios close to 120 (Negrel et al 1993; Meybeck 1986; Stallard 1980). The chemical composition assigned for silicate end member is $\mathrm{Ca} / \mathrm{Na}=0.35 \pm 0.15$, $\mathrm{Mg} / \mathrm{Na}=0.24 \pm 0.12$, and $\mathrm{HCO}_{3} / \mathrm{Na}=2 \pm 1$ (Gaillardet et al 1999). The observed equivalent ratios of $\mathrm{Ca} / \mathrm{Na}=2.85 \pm 1.15, \mathrm{Mg} / \mathrm{Na}=2.76 \pm$ 1.01 and $\mathrm{HCO}_{3} / \mathrm{Na}=3.73 \pm 0.94$ in the meltwater of Gangotri Glacier are higher than those of meltwaters draining silicate lithology and much lower than those of waters draining carbonate lithology. These ratios indicate that chemical composition of the meltwater of Gangotri Glacier is influenced by carbonate weathering followed silicate weathering.

The scatter plot of $(\mathrm{Ca}+\mathrm{Mg})$ vs. $\left(\mathrm{HCO}_{3}+\mathrm{SO}_{4}\right)$ (figure 3a) shows good correlation throughout the range of data, though plotted points tend to fall above $1: 1$ equiline requiring a portion of the $\left(\mathrm{HCO}_{3}+\mathrm{SO}_{4}\right)$ to be balanced by cations $(\mathrm{Na}+\mathrm{K})$ from weathering of silicate rocks (Pandey et al 1999). The scatter plot of $(\mathrm{Ca}+\mathrm{Mg})$ vs. $\mathrm{SO}_{4}^{2-}$ (figure $3 \mathrm{~b}$ ) shows significant correlation between $(\mathrm{Ca}+\mathrm{Mg})$ and $\mathrm{SO}_{4}^{2-}\left(r^{2}=0.93\right)$ indicating that $\mathrm{CaSO}_{4}$ and $\mathrm{MgSO}_{4}$ contribute sulphate to the meltwater of Gangotri Glacier. The first possibility is that $\mathrm{SO}_{4}^{2-}$ content in the glacier melt could have acquired through dissolution of sulphate minerals (gypsum and anhydrite). The second possibility is that $\mathrm{SO}_{4}^{2-}$ has been derived through sulphide oxidation (equation 5) (Srivastava et al 2004). Trace amount of $\mathrm{NO}_{3}^{-}$was also reported from the study area, indicating palatability of water. The $\mathrm{NO}_{3}^{-}$in the monsoon season indicates possible influence of atmospheric deposition associated with the acidic $\mathrm{NO}_{3}^{-}$aerosol (Tranter et al 1993) coupled with possible contribution from anthropogenic activities in the sampling area.

The most important mechanism responsible for rock mineral weathering is acid hydrolysis (Raiswell 1984). In the bulk stream water, the relative proportions of $\mathrm{HCO}_{3}^{-}$and $\mathrm{SO}_{4}^{2-}$ reflect the dominance of the two major sources of aqueous protons driving subglacial chemical weathering reactions (Raiswell 1984; Tranter et al 1993; Brown et al 1996).

$$
\begin{gathered}
\mathrm{CO}_{2}+\mathrm{H}_{2} \mathrm{O} \leftrightarrow \mathrm{H}_{2} \mathrm{CO}_{3} \\
\mathrm{H}_{2} \mathrm{CO}_{3} \leftrightarrow \mathrm{H}^{+}+\mathrm{HCO}_{3}^{-} \\
\mathrm{CaCO}_{3}(\mathrm{~s})+\mathrm{H}_{2} \mathrm{CO}_{3}(\mathrm{aq}) \\
\leftrightarrow \mathrm{Ca}^{2+}(\mathrm{aq})+2 \mathrm{HCO}_{3}^{-}(\mathrm{aq}) \\
\mathrm{CaMg}\left(\mathrm{CO}_{3}\right)_{2}(\mathrm{~s})+2 \mathrm{H}_{2} \mathrm{CO}_{3}(\mathrm{aq}) \\
\leftrightarrow \mathrm{Ca}^{2+}(\mathrm{aq})+\mathrm{Mg}^{2+}(\mathrm{aq})+4 \mathrm{HCO}_{3}^{-}(\mathrm{aq})
\end{gathered}
$$

$4 \mathrm{FeS}_{2}(\mathrm{~s})+15 \mathrm{O}_{2}(\mathrm{aq})+14 \mathrm{H}_{2} \mathrm{O}(\mathrm{l})$

$$
\leftrightarrow 4 \mathrm{Fe}(\mathrm{OH})_{3}(\mathrm{~s})+8 \mathrm{SO}_{4}^{2-}(\mathrm{aq})+16 \mathrm{H}^{+}(\mathrm{aq})
$$

The general reaction of weathering of silicate minerals with $\mathrm{H}_{2} \mathrm{CO}_{3}$ can be written as (Anshumali and Ramanathan 2007):

$$
\begin{aligned}
& (\mathrm{Na}, \mathrm{K}, \mathrm{Ca}, \mathrm{Mg}) \text { silicate }+\mathrm{H}_{2} \mathrm{CO}_{3} \\
& \leftrightarrow \mathrm{H}_{4} \mathrm{SiO}_{4}+\mathrm{HCO}_{3}^{-}+\mathrm{Na}^{+}+\mathrm{K}^{+}+\mathrm{Ca}^{2+} \\
& \quad+\mathrm{Mg}^{2+}+\text { Solid products }
\end{aligned}
$$

The relative importance of two major proton producing reactions - carbonation and sulphide oxidation can be evaluated on the basis of the C-ratio. Brown et al (1996) proposed estimation of $\mathrm{C}$ ratio $\left(\mathrm{HCO}_{3} / \mathrm{HCO}_{3}+\mathrm{SO}_{4}\right)$. If $\mathrm{C}$ ratio is 1.0 , it indicates the significance of carbonation reaction involving acid hydrolysis and pure dissolution, consuming protons from atmospheric $\mathrm{CO}_{2}$ (equations 1, 2 and

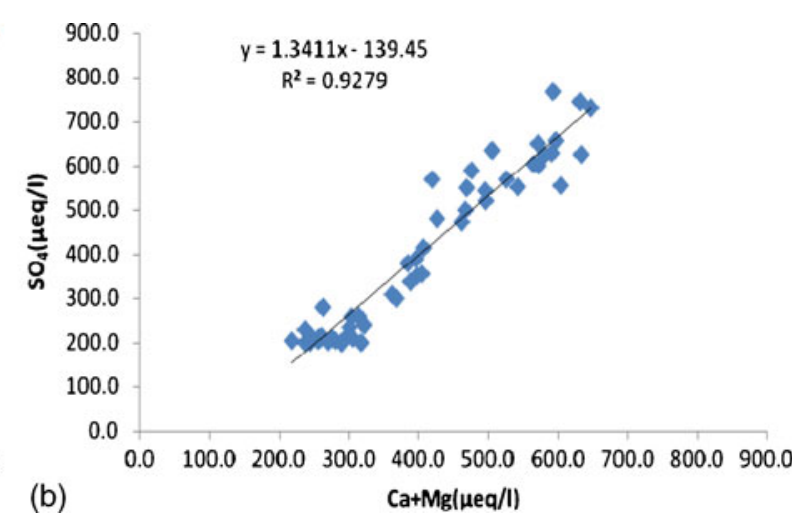

(b) (a)

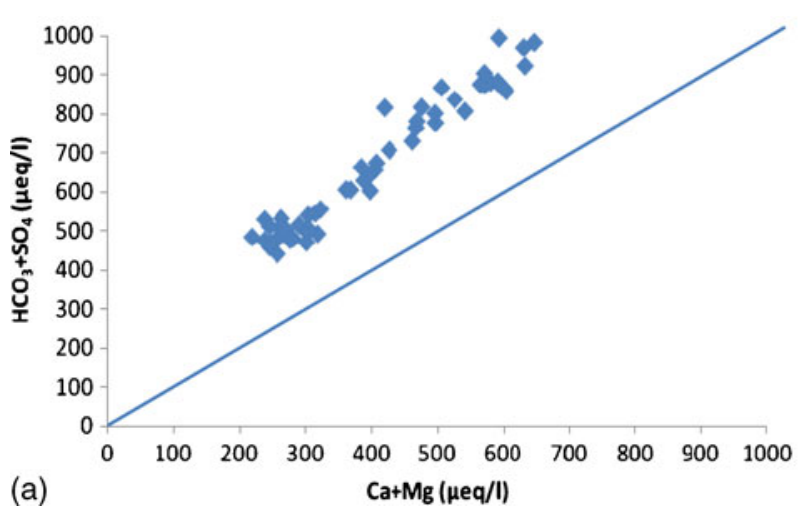

Figure 3. (a) Scatter plot between $\mathrm{Ca}+\mathrm{Mg}$ and $\mathrm{HCO}_{3}+\mathrm{SO}_{4}$. (b) Scatter plot between $\mathrm{Ca}+\mathrm{Mg}$ and $\mathrm{SO}_{4}$. 
3). Conversely if $\mathrm{C}$ ratio is 0.5 , it suggests coupled reaction involving carbonate weathering and protons derived from oxidation of sulphide (equation 5). The average C-ratio for the meltwater of Gangotri Glacier is $0.43 \pm 0.13$, which suggests that the major proton producing reaction is sulphide oxidation. The coupled reactions involving dissolution of $\mathrm{CO}_{2}$, carbonate dissolution and protons derived from sulphide mineral oxidation control the hydrochemistry of Gangotri Glacier. This ratio is similar to the results obtained for the nearby Dudu Glacier meltwater stream in Ganga head-water (Ahmad and Hasnain 2001).

Contribution of atmospheric input to the chemical composition of river water has been studied by many researchers (Biksham and Subramanian 1988; Meybeck 1983; Sarin et al 1989; Pandey et al 1999). The importance of atmospheric input for river water composition can also be determined by the ratio of ions to chloride. The scatter plot of $(\mathrm{Na}+\mathrm{K})$ vs. $\mathrm{Cl}^{-}$(figure 4$)$ shows that $(\mathrm{Na}+\mathrm{K})$ content is much higher than $\mathrm{Cl}^{-}$and average $\mathrm{Na}+\mathrm{K} / \mathrm{Cl}$ ratio for the study area is significantly higher than expected from marine aerosols. The average equivalent ratios of $\mathrm{Na} / \mathrm{Cl}=13.5 \pm 11.2$ and $\mathrm{K} / \mathrm{Cl}=14.9 \pm 12.7$ are significantly higher than those of sea water (i.e., $\mathrm{Na} / \mathrm{Cl}=1.0$ and $\mathrm{K} / \mathrm{Cl}=0.2$ respectively). These ratios indicate relatively minor contribution from atmospheric precipitation to the observed dissolved ion budgets of the meltwater of Gangotri Glacier as reported by other researchers (Pandey et al 1999; Kumar et al 2009). Sarin et al (1992) estimated that atmospheric deposition may contribute up to $20 \%$ of $\mathrm{Na}^{+}$and $\mathrm{K}^{+}$and up to $5 \%$ of the $\mathrm{Ca}^{2+}, \mathrm{Mg}^{2+}$ and $\mathrm{SO}_{4}^{2-}$ to the major ions chemistry of Ganga source water. The observed high ratios of $\mathrm{Na} / \mathrm{Cl}$ and $\mathrm{K} / \mathrm{Cl}$ may also be indicative of the contribution from salt dissolution from evaporites. But the observed high equivalent ratio of $\mathrm{Mg} / \mathrm{Na}=2.76 \pm 1.01$ and low concentration of chloride along with less abundance of evaporites from the geological formation indicate that fraction of cations derived from

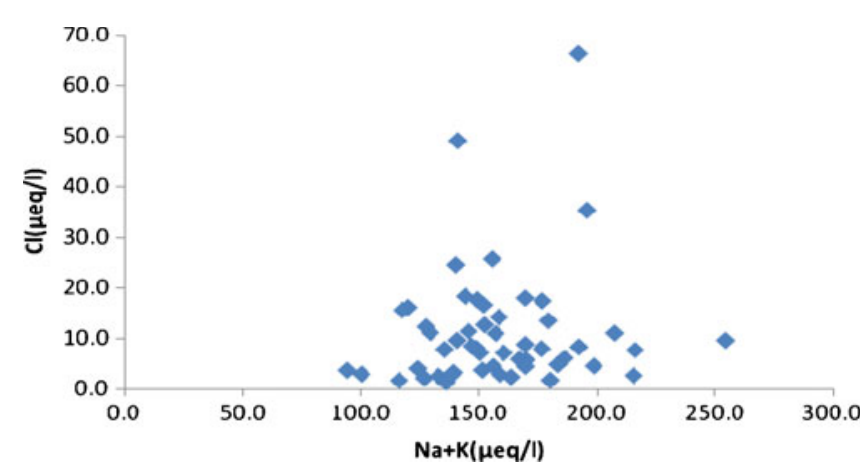

Figure 4. Scatter plot between $\mathrm{Na}+\mathrm{K}$ and $\mathrm{Cl}$. evaporites accompanying $\mathrm{Cl}^{-}$is likely to be negligible (Pandey et al 1999). Thus the observations indicate the limited contribution of evaporite dissolution and atmospheric input in comparison to the contribution from rock weathering (carbonate and silicate) which is the major pathway controlling the hydrochemistry of the Gangotri Glacier.

Stability of minerals is an important way in which the approach to the equilibrium between natural water and clay minerals can be verified through thermodynamic data (Garrels and Christ 1965). The thermodynamic stability relationship plot of water chemistry in $\mathrm{Na}, \mathrm{K}, \mathrm{Ca}$ and $\mathrm{Mg}$ silicate system are given in figure 5 . The $\mathrm{pH}-\mathrm{log}$ $\mathrm{H}_{4} \mathrm{SiO}_{4}$ relation demonstrates that chemical composition of the meltwater of Gangotri Glacier falls in the region of kaolinite, implying that hydrochemistry favours kaolinite formation. X-Ray mineralogical studies of suspended sediment are to be carried out to support the above observation.

Meltwater evolution and relationship between water composition and rock type can be evaluated by plotting the concentrations of major cations and anions in the (Piper 1944) Tri-linear diagram. The Piper plot (figure 6) showed that majority of samples fell in the category of $\mathrm{Ca}-\mathrm{SO}_{4}$ type water. But a considerable number of samples also fell in $\mathrm{Mg}-\mathrm{SO}_{4}, \mathrm{Mg}-\mathrm{HCO}_{3}$ and $\mathrm{Ca}-\mathrm{HCO}_{3}$ types of water. From Piper plot, it is clear that alkaline earth metals $(\mathrm{Ca}+\mathrm{Mg})$ are significantly higher than alkalis $(\mathrm{Na}+\mathrm{K})$ and strong acids $\left(\mathrm{SO}_{4}+\mathrm{Cl}\right)$ dominated over weak acids $\left(\mathrm{HCO}_{3}+\mathrm{CO}_{3}\right)$. This further confirms that carbonate weathering is the major source for the dissolved ions.

\subsection{Effective $\mathrm{CO}_{2}$ pressure}

The effective $\mathrm{CO}_{2}$ pressure or internal $\mathrm{CO}_{2}$ pressure $\left(\mathrm{Log} \mathrm{pCO}_{2}\right)$ has been estimated from $\mathrm{pH}$ values and $\mathrm{HCO}_{3}^{-}$concentration. The $\mathrm{pCO}_{2}$ of a solution reflects the rate at which $\mathrm{CO}_{2}$ diffuses into or out of solution relative to the rate of other chemical weathering reactions (Raiswell 1984; Raiswell and Thomas 1984; Thomas and Raiswell 1984). The $\mathrm{pCO}_{2}$ signature of meltwater can be used to characterize different glacial hydrological weathering environments (Sharp 1991; Wadham et al 1998). If $\mathrm{pCO}_{2}$ of solutions are not equal to atmospheric $\mathrm{pCO}_{2}\left(10^{-3.5} \mathrm{~atm}\right)$, it can be said to be in disequilibrium with respect to the atmosphere. When the supply of protons is more than their consumption, then high $\mathrm{pCO}_{2}$ conditions arise. $\mathrm{CO}_{2}$ diffuses out from the solution, with the conversion of some $\mathrm{HCO}_{3}^{-}$to $\mathrm{CO}_{2}$ and loss of protons from solution. Low $\mathrm{pCO}_{2}$ conditions arise when the demand of protons for chemical weathering is more than the rate of $\mathrm{CO}_{2}$ diffusion 
Na-System
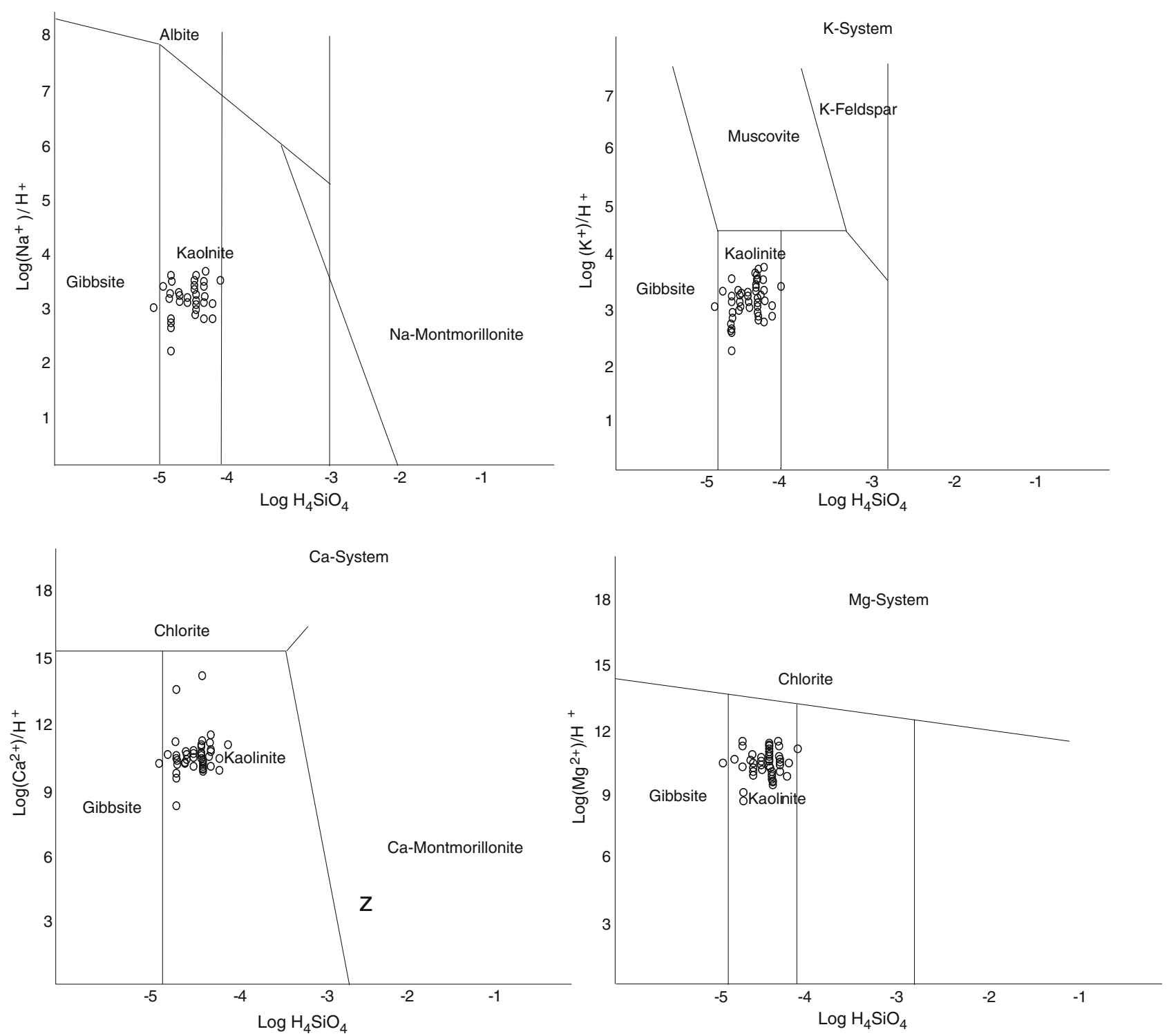

Figure 5. Stability diagram for $\mathrm{Na}, \mathrm{K}, \mathrm{Ca}$ and $\mathrm{Mg}$ silicate systems.

into solution (Wadham et al 1998). The average $\mathrm{pCO}_{2}$ value for meltwater of Gangotri Glacier was slightly higher $\left(10^{-2.9}\right)$ than the atmospheric value $\left(10^{-3.5}\right)$ indicating open system weathering. This is a global trend that river water shows disequilibrium with the atmosphere (Garrels and Mackenzie 1971; Raymahasay 1986). The slightly higher values of $\mathrm{pCO}_{2}$ could be explained by the relative higher rate of solubility in comparison to release of excess of $\mathrm{CO}_{2}$ gas in a turbulent and low temperature environment (Stumm and Morgan 1970). The average $\mathrm{pCO}_{2}$ value for this study area is comparable with the earlier reported value for Alaknanda River basin (Singh and Hasnain 1998). High $\mathrm{pCO}_{2}$ values are likely to arise from the coupling of sulphide oxidation and carbonate dissolution (Wadham et al 1998).

\subsection{Statistical analysis}

Correlation analysis is a bivariate method commonly used to measure and establish the relationship between two variables. It is a statistical tool used to measure the degree of dependency of one variable to other. A parametric correlation analysis of measured parameter is given in table 2. Strong correlation was observed between $\mathrm{Ca}^{2+}$ and $\mathrm{Mg}^{2+}$ $\left(r^{2}=0.888\right)$ and $\mathrm{Na}^{+}$and $\mathrm{K}^{+}\left(r^{2}=0.827\right)$ indicating the same source, which may be carbonate and silicate weathering respectively. Good correlation was also observed between $\mathrm{Ca}^{2+}$ and $\mathrm{SO}_{4}^{2-}\left(r^{2}=\right.$ $0.95)$ and $\mathrm{Mg}^{2+}$ and $\mathrm{SO}_{4}^{2-}\left(r^{2}=0.919\right)$, probably resulting from dissolution of sulphate minerals, pyrite oxidation and secondary leaching of $\mathrm{SO}_{4}^{2-}$ from evaporites. 


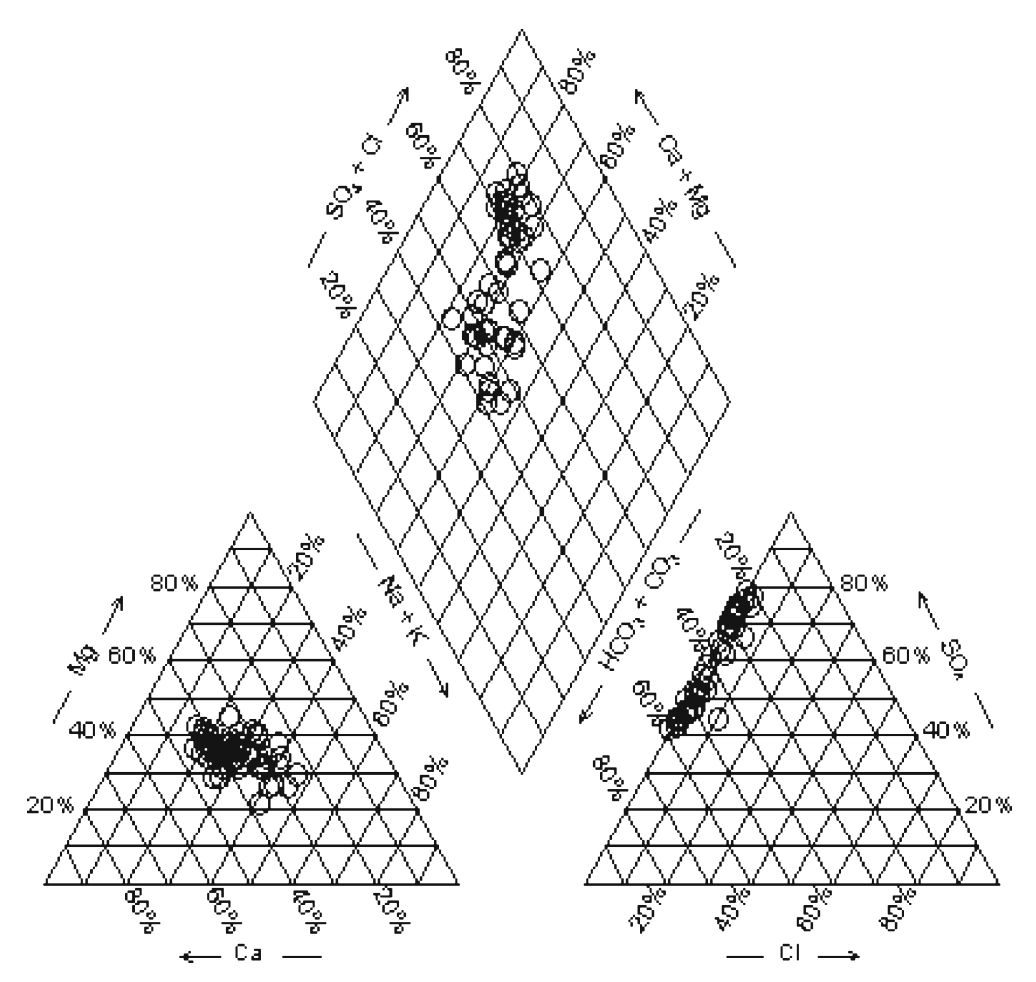

Figure 6. Piper plot for concentration of ions.

Factor analysis is an important statistical method used to explain observed relationships among numerous variables. The mode of factor analysis is R-mode or Q-mode. Factor analysis is termed R-mode when the concern is interrelationships among the variables and Q-mode when concern is the interrelationships between samples (Singh and Hasnain 2002). R-mode factor analysis was used to identify major factors controlling the hydrochemistry of Gangotri Glacier. Factor analysis results of meltwater of study area were given in table 3 . When the corresponding eigenvalue is greater than 1 , it is said to be significant contribution of factor. Three factors with an eigenvalue $>1$ were identified. These three factors explain about $68 \%$ of the total variance.
Factor 1 accounts for $38.2 \%$ variance in the dataset and shows high loading of $\mathrm{H}_{4} \mathrm{SiO}_{4}, \mathrm{SO}_{4}^{2-}, \mathrm{Ca}^{2+}$ and $\mathrm{Mg}^{2+}$ and negative loading of $\mathrm{HCO}_{3}^{-}$. This factor explains contribution from carbonate/silicate weathering, sulphate mineral dissolution, carbonation and sulphide oxidation. $\mathrm{HCO}_{3}^{-}$might have derived from carbonate dissolution, hence showing negative loading in comparison to $\mathrm{Ca}^{2+}, \mathrm{Mg}^{2+}$, $\mathrm{Na}^{+}$and $\mathrm{K}^{+}$. Factor 2 accounts for $17.6 \%$ variance in the dataset and shows strong loading of $\mathrm{pH}, \mathrm{Na}^{+}$and $\mathrm{K}^{+}$. This factor describes contribution from weathering of silicate minerals. Factor 3 accounts for $12.2 \%$ variance in dataset and shows high loading of $\mathrm{Cl}^{-}$. This factor represents contribution from evaporites and atmospheric precipitation.

Table 2. Correlation matrix of measured parameters in Gangotri Glacier meltwater.

\begin{tabular}{|c|c|c|c|c|c|c|c|c|c|c|}
\hline & $\mathrm{pH}$ & $\mathrm{H}_{4} \mathrm{SiO}_{4}$ & $\mathrm{NO}_{3}$ & $\mathrm{Cl}$ & $\mathrm{HCO}_{3}$ & $\mathrm{SO}_{4}$ & $\mathrm{Na}$ & $\mathrm{K}$ & $\mathrm{Ca}$ & $\mathrm{Mg}$ \\
\hline $\mathrm{pH}$ & 1.000 & & & & & & & & & \\
\hline $\mathrm{H}_{4} \mathrm{SiO}_{4}$ & 0.174 & 1.000 & & & & & & & & \\
\hline $\mathrm{NO}_{3}$ & 0.098 & 0.038 & 1.000 & & & & & & & \\
\hline $\mathrm{Cl}$ & 0.062 & 0.131 & 0.126 & 1.000 & & & & & & \\
\hline $\mathrm{HCO}_{3}$ & -0.139 & -0.382 & -0.147 & 0.048 & 1.000 & & & & & \\
\hline $\mathrm{SO}_{4}$ & 0.038 & 0.637 & 0.126 & 0.022 & -0.530 & 1.000 & & & & \\
\hline $\mathrm{Na}$ & 0.244 & 0.258 & 0.150 & -0.002 & -0.215 & 0.233 & 1.000 & & & \\
\hline K & 0.243 & 0.296 & 0.066 & 0.246 & -0.276 & 0.327 & 0.827 & 1.000 & & \\
\hline $\mathrm{Ca}$ & -0.037 & 0.587 & 0.130 & 0.124 & -0.393 & 0.950 & 0.070 & 0.181 & 1.000 & \\
\hline $\mathrm{Mg}$ & -0.030 & 0.567 & 0.060 & 0.031 & -0.350 & 0.919 & -0.029 & 0.072 & 0.888 & 1.000 \\
\hline
\end{tabular}


Table 3. Principal and varimax rotated $R$-mode factor loading matrix.

\begin{tabular}{lcccc}
\hline Variables & Factor 1 & Factor 2 & Factor 3 & Communalities \\
\hline $\mathrm{pH}$ & - & 0.602 & -0.176 & 0.393 \\
$\mathrm{H}_{4} \mathrm{SiO}_{4}$ & 0.702 & 0.248 & 0.113 & 0.567 \\
$\mathrm{NO}_{3}$ & - & 0.137 & 0.415 & 0.194 \\
$\mathrm{Cl}$ & - & - & 0.762 & 0.586 \\
$\mathrm{HCO}_{3}$ & -0.532 & -0.330 & 0.123 & 0.407 \\
$\mathrm{SO}_{4}$ & 0.977 & 0.117 & - & 0.977 \\
$\mathrm{Na}$ & 0.103 & 0.863 & 0.175 & 0.786 \\
$\mathrm{~K}$ & 0.183 & 0.835 & 0.310 & 0.826 \\
$\mathrm{Ca}$ & 0.941 & - & 0.230 & 0.945 \\
$\mathrm{Mg}$ & 0.937 & -0.125 & - & 0.893 \\
Eigen value & 4.590 & 2.107 & 1.466 & \\
$\%$ of variance & 38.247 & 17.556 & 12.218 & \\
$\%$ of cumulative variance & 38.247 & 55.802 & 68.02 & \\
\hline
\end{tabular}

\subsection{Temporal variation of the total dissolved solids (TDS)}

Variations in the concentration of different ions with time are possibly due to different weathering intensities generating meltwater at different discharge values (Kumar et al 2009). There has been a marked temporal variation in the TDS of the meltwater draining from Gangotri Glacier. TDS was high in the mornings and reduced towards evenings (figure 7). The model of Rainwater and Guy (1961), Collins (1983), Kumar et al (2009), was used to explain the observed temporal variation in the TDS. In the morning, low supply of solar energy reduced the melting and dilution of subglacial water. The subglacial water produced at pressure melting point, has high ionic chemical enrichment as a result of high residence time and longer contact with the solute rich base. In the afternoon with an increase in insolation, englacial channels become active and large amount of supraglacial meltwaters become available for transportation so that discharge is maximum in the evening, resulting in increased dilution of TDS.

\subsection{Average chemical composition of Gangotri Glacier meltwater and comparison with other Himalayan glaciers' meltwater}

The summary of chemical composition of meltwater draining from Gangotri Glacier and other selected Himalayan glaciers are given in table 4 . The abundance of anions in the meltwaters of Kafni, Dokriani and Chhota Shigri glaciers varied as $\mathrm{HCO}_{3}^{-}>\mathrm{SO}_{4}^{2-}>\mathrm{Cl}^{-}$while in Bagni Glacier it varied as $\mathrm{SO}_{4}^{2-}>\mathrm{HCO}_{3}^{-}>\mathrm{Cl}^{-}$. In Dudu and Gangotri glacier meltwaters the abundance order was $\mathrm{SO}_{4}^{2-}>\mathrm{HCO}_{3}^{-}>\mathrm{NO}_{3}^{-}>\mathrm{Cl}^{-}$and $\mathrm{SO}_{4}^{2-}>$ $\mathrm{HCO}_{3}^{-}>\mathrm{Cl}^{-}>\mathrm{NO}_{3}^{-}$respectively. The abundance of cations in the meltwaters of Dokariani and Gangotri glaciers varied as follows: $\mathrm{Ca}^{2+}>\mathrm{Mg}^{2+}>$ $\mathrm{K}^{+}>\mathrm{Na}^{+}$; whereas in Kafni and Chhota Shigri glaciers, it varied as $\mathrm{Ca}^{2+}>\mathrm{Mg}^{2+}>\mathrm{Na}^{+}>\mathrm{K}^{+}$. In

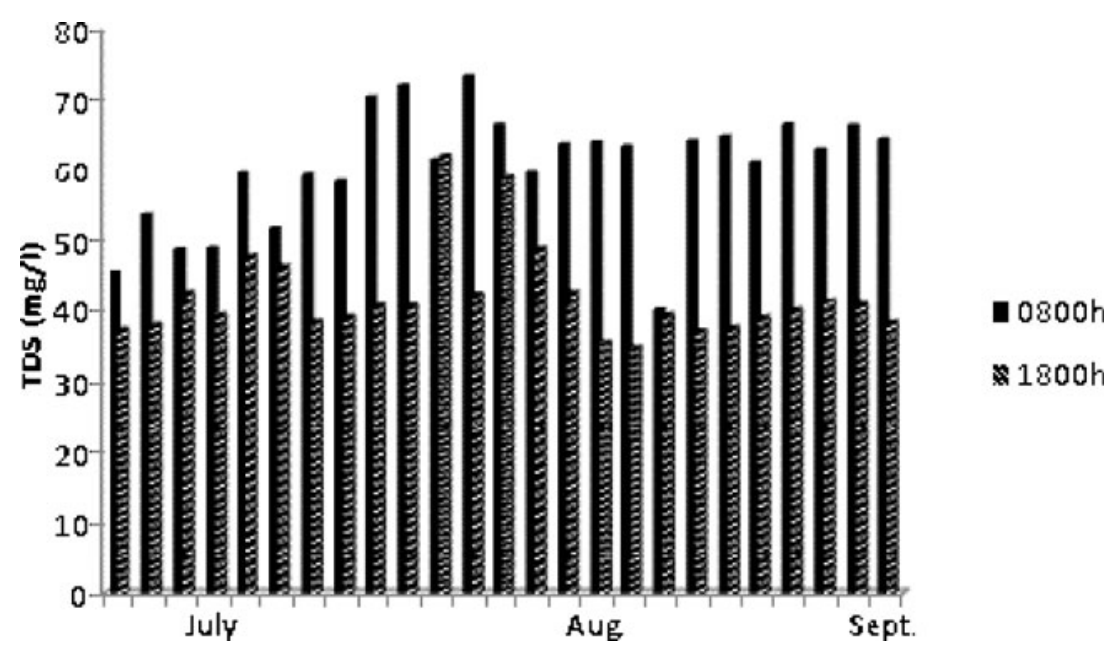

Figure 7. Temporal variation of the TDS in Gangotri Glacier meltwater. 
Table 4. Average chemical composition of Gangotri Glacier meltwater and comparison with other Himalayan glacier meltwaters.

\begin{tabular}{|c|c|c|c|c|c|c|c|c|c|c|c|c|}
\hline Glacier & $\mathrm{EC}$ & $\mathrm{pH}$ & $\mathrm{Ca}^{2+}$ & $\mathrm{Mg}^{2+}$ & $\mathrm{Na}^{+}$ & $\mathrm{K}^{+}$ & $\mathrm{HCO}_{3}^{-}$ & $\mathrm{SO}_{4}^{2-}$ & $\mathrm{Cl}^{-}$ & $\mathrm{NO}_{3}^{-}$ & $\mathrm{H}_{4} \mathrm{SiO}_{4}$ & References \\
\hline Kafni & 89.2 & 7.2 & 587 & 165 & 65 & 31 & 623 & 76 & 35 & - & 28 & Singh et al (1998) \\
\hline Bagni & 122 & 7.6 & 680 & 269 & 21 & 457 & 1557 & 1710 & 13.4 & - & - & Ahmad and Hasnain (2000) \\
\hline Dudu & 31.9 & 6.3 & 91.1 & 6.5 & 42.7 & 24.6 & 52.3 & 85.4 & 5.0 & 14.9 & 36.0 & Ahmad and Hasnain (2001) \\
\hline Dokriani & 48.2 & 7.0 & 271 & 100 & 64 & 116 & 625 & 406 & 16 & - & - & Ahmad and Hasnain (2000) \\
\hline Chhota Shigri & 85.6 & 7.4 & 530 & 238 & 104 & 76 & 295 & 279 & 25 & - & - & Sharma (2007) \\
\hline Gangotri & 81 & 7.2 & 206 & 197 & 75 & 83 & 266 & 401 & 11.2 & 1.9 & 64 & Present study \\
\hline
\end{tabular}

Unit: Dissolved ions in $\mu \mathrm{eq} / \mathrm{l}$; $\mathrm{EC}$ in $\mu \mathrm{s} / \mathrm{cm}$ and $\mathrm{H}_{4} \mathrm{SiO}_{4}$ in $\mu \mathrm{mole} / \mathrm{l}$.

Bagni and Dudu glacier meltwaters the abundance order was $\mathrm{Ca}^{2+}>\mathrm{K}^{+}>\mathrm{Mg}^{2+}>\mathrm{Na}^{+}$and $\mathrm{Ca}^{2+}>$ $\mathrm{Na}^{+}>\mathrm{K}^{+}>\mathrm{Mg}^{2+}$ respectively.

The average $(\mathrm{Ca}+\mathrm{Mg}) /(\mathrm{Na}+\mathrm{K})$ ratios for Kafni, Bagni, Dudu, Dokriani, Chhota Shigri and Gangotri glaciers are 8.00, 1.99, 1.40, 2.06, 4.27 and 2.63 which indicate the dominance of carbonate weathering as a major source of dissolved ions in the glacier basin, even when calcite is present in low concentrations (Raiswell 1984). The average $(\mathrm{Na}+\mathrm{K}) / \mathrm{Cl}$ ratios are 3.0, 35.7, 13.5, 11.3, 7.2 and 28.3 for Kafni, Bagni, Dudu, Dokriani, Chhota Shigri and Gangotri glaciers, respectively. These ratios are significantly higher than the expected from marine aerosols, suggesting little contribution from atmospheric input (Singh et al 1998; Ahmad and Hasnain 2000, 2001; Sharma 2007). Chemical characteristics of meltwater draining from different glaciers are in equilibrium with the bedrock terrain over which the glaciers flow (Meybeck 1981). Meltwater draining from Kafni Glacier shows high percentage of calcium and bicarbonate because of the presence of calcareous band and calc-silicate rocks in the glacier basin (Singh and Hasnain 1998). Whereas, meltwater draining from Bagni Glacier shows quite different characteristics with respect to other glacier meltwaters, because this glacier lies on Martoli Formation constituted of phyllite, which is responsible for high EC and high $\mathrm{pH}$ and exceptionally high potassium percentage in the meltwater (Ahmad and Hasnain 2000). Gangotri, Chhota Shigri, Bagni and Dokriani glaciers show high sulphate concentration, may be due to pyrite dissolution in the bed rock (Bhatt 1963; Sharma 2007). Another reason for high concentration of sulphate as compared to other ions in the meltwater of Gangotri Glacier may be dissolution of sulphate minerals (gypsum and anhydrite) (Srivastava et al 2004).

\section{Conclusion}

The Gangotri Glacier meltwater is alkaline in nature. Cationic abundance order is $\mathrm{Ca}^{2+}>\mathrm{Mg}^{2+}>$ $\mathrm{K}^{+}>\mathrm{Na}^{+}$, while anionic abundance order is
$\mathrm{SO}_{4}^{2-}>\mathrm{HCO}_{3}^{-}>\mathrm{Cl}^{-}>\mathrm{NO}_{3}^{-}$. Calcium and magnesium are the dominant cations, while sulphate is dominant anion followed by bicarbonate. The high $(\mathrm{Ca}+\mathrm{Mg})$ vs. $\mathrm{TZ}^{+},(\mathrm{Ca}+\mathrm{Mg}) /(\mathrm{Na}+\mathrm{K})$ ratios and low $(\mathrm{Na}+\mathrm{K}) / \mathrm{TZ}^{+}$ratio indicate that chemical characteristics of meltwater draining from Gangotri Glacier System is largely controlled by carbonate weathering and partly controlled by silicate weathering. Coupled reactions involving sulphide oxidation and carbonation also seem to play a major role in controlling the solute acquisition process. Sulphide oxidation is the major proton producing reaction in the meltwater of Gangotri Glacier.

The equivalent ratios of $\mathrm{Na} / \mathrm{Cl}$ and $\mathrm{K} / \mathrm{Cl}$ are significantly higher than those of marine aerosols indicating minimal contribution from atmospheric precipitation to the dissolved ion budgets of the meltwater of Gangotri Glacier. Water types from Piper plots indicate the dominance of alkaline earth metals over the alkali metals and strong acids over weak acids in the meltwater. The average $\mathrm{pCO}_{2}$ value for the meltwater of Gangotri Glacier is slightly higher than the atmospheric value indicating open system weathering and shows disequilibrium with respect to the atmosphere. The results of factor analysis indicate that carbonate/ silicate weathering, sulphate mineral dissolution and sulphide oxidation along with atmospheric contribution regulate the major ion chemistry.

\section{Acknowledgements}

The authors are thankful to the Department of Science and Technology (DST), Govt. of India for funding the research project on Gangotri Glacier. The authors are also grateful to Jawaharlal Nehru University for providing the research facilities.

\section{References}

Ahmad S and Hasnain S I 2000 Meltwater characteristics of Garhwal Himalayan glaciers; J. Geol. Soc. India 56 431-439. 
Ahmad S and Hasnain S I 2001 Chemical characteristics of stream draining from Dudu glacier: An Alpine meltwater stream in Ganga Headwater, Garhwal Himalaya; J. China Univ. Geosci. 12 75-83.

Anshumali and Ramanathan A L 2007 Seasonal variation in the major ion chemistry of Pandoh lake, Mamdi district, Himachal Pradesh, India; Appl. Geochem. 22 1736-1747.

APHA (American Public Health Association) 2005 Standard methods for examination of water and wastewater; $21 \mathrm{st}$ edn., Washington, D.C., 6710p.

Bassi U K 2004 Geology of the Gangotri-Gaumukh area, Uttarkashi district, Uttaranchal, Proc. Workshop on Gangotri Glacier; Geol. Surv. India Spec. Publ. 80 235-239.

Beherens H, Bergmann H, Moser H, Rauert W, Stichler W, Eisner H and Pessel K 1971 Study of the discharge of alpine glaciers by means of environmental isotopes and dye tracers; Zeitscherkd Glazialgeo 7 79-102.

Bhatt B K 1963 Preliminary study of the Bhagirathi basin between Uttarkashi and Gomukh; In: Proceeding of National Symposium on Himalayan Geology, Calcutta; Geol. Soc. India. Misc. Publ. 15 1-8.

Biksham G and Subramanian V 1988 Nature of solute transport in the Godavari basin, India; J. Hydrol. 103 375-392.

Brown G H 2002 Glacier meltwater hydrochemistry; Appl. Geochem. 17 855-883.

Brown G H, Tranter M and Sharp M 1996 Subglacial chemical erosion - seasonal variations in solute provenance, Haut Glacier d'Arolla, Switzerland; Ann. Glaciol. 22 25-31.

Collins D N 1978 Hydrology of an Alpine glacier as indicated by the chemical composition of meltwater; Z. Gletscherkd. Glazialgeol. 13 219-238.

Collins D N 1979a Hydrochemistry of meltwater draining from an Alpine glacier; Arctic and Alpine Research 11 307-324.

Collins D N 1979b Sediment concentration in meltwater as an indicator of erosion process beneath Alpine glacier; J. Glaciol. 23(89) 247-257.

Collins D N 1983 Solute yield from a glacierised high mountain basin; In: Symposium on dissolved loads of rivers and surface water quality/quantity relationship (ed.) Webb B W; Int. Assoc. Hydrol. Sci. Publ. 141 41-50.

Florence T M and Farrar Y J 1971 Spectrophotometric determination of chloride at the parts-per-billion level by the mercury (II) thiocyanate method; Anal. Chim. Acta 54 373-377.

Gaillardet J, Dupre B, Louvat P and Allegre C J 1999 Global silicate weathering and silicate weathering and $\mathrm{CO}_{2}$ consumption rates deduced from the chemistry of large rivers; Chem. Geol. 159 3-30.

Gansser A 1964 Geology of the Himalayas (New York: Interscience), 289p.

Garrels R M and Christ C L 1965 Solutions, minerals and equilibria (New York: Harper and Row), 450p.

Garrels R M and Mackenzie F T 1971 Evolution of sedimentary rocks (New York: W W Norton), 450p.

Heim A and Gansser A 1939 The Central Himalayas: Geological observations of the Swiss Expedition of 1936; Mem. Soc. Helv; Sci. Nat. 73 1-245.

Jowhar T N 2010 Chemistry of Tourmalines from the Gangotri Granite, Garhwal Higher Himalaya; Earth Science India 3 181-194.

Kumar K, Miral M S, Joshi S, Pant N, Joshi V and Joshi L M 2009 Solute dynamics of meltwater of Gangotri glacier, Garhwal Himalaya, India; Environ. Geol. 58 1151-1159.

Le Fort P 1975 Himalayas: The collided range, present knowledge of the continental arc; Am. J. Sci. 275 1-44.
Lorrain R D and Souchez R A 1972 Sorption as a factor in the transport of major cations by meltwater from an Alpine glacier; Quat. Res. 2(2) 253-256.

Meybeck M 1981 Pathways of major elements from land to ocean through river; In: River inputs to ocean system; UNEP/UNESCO Rept., pp. 18-30.

Meybeck M 1983 Atmospheric inputs and river transport of dissolved substances; In: Dissolved loads of rivers and surface water quality/quantity relationships (ed.) Webb B W; Int. Assoc. Hydrol. Sci. Publ. 141 173-191.

Meybeck M 1986 Compositiondes ruisseau non pollues de France; Sci. Geo. Bull. 39 3-77.

Naithani A K, Nainwal H C, Sati K K and Prasad C 2001 Geomorphological evidences of retreating of Gangotri glacier and its characteristics; Curr. Sci. 80(1) 87-94.

Negrel P, Allegre C J, Dupre B and Lewin E 1993 Erosion sources determined by inversion of major and trace element ratios in river water: The Congo basin case; Earth Planet. Sci. Lett. 120 59-76.

Ostrem G 1975 Sediment transport in glacial meltwater stream; In: Glacio-fluvial and Glacio-lacustrine sedimentation (eds) Jopling A V and McDonald B C, Soc. Econ. Palaeontol. Mineral., Spec. Publ. 23 101-122.

Pandey S K, Singh A K and Hasnain S I 1999 Weathering and geochemical processes controlling solute acquisition in Ganga Headwater-Bhagirathi river, Garhwal Himalaya, India; Aquat. Geochem. 5 357-379.

Piper A M 1944 A graphical procedure in the geochemical interpretation of water analysis; Trans. Am. Geophys. Union 25 914-923.

Raina V K and Srivastava D 2008 Glacier Atlas of India (Bangalore: Geological Society of India), 316p.

Rainwater F H and Guy H P 1961 Some observations on the hydrochemistry and sedimentation of the Chamberlain Glacier Area Alaska; US Geol. Surv. Prof. Paper 414-c $\mathrm{c} 1-\mathrm{c} 14$.

Raiswell R 1984 Chemical models of solute acquisition in glacial meltwater; J. Glaciol. 30(104) 49-57.

Raiswell R and Thomas A G 1984 Solute acquisition in glacial meltwaters. I: Fjallsjokull (south-east Iceland): Bulk meltwaters with closed system characteristics; J. Glaciol. 30(104) 35-43.

Raymahasay B C 1986 Geochemistry of bicarbonate in the river water; J. Geol. Soc. India 27 114-118.

Reynolds R C and Johnson N M 1972 Chemical weathering in the temperate glacial environment of the Northern Cascade Mountains; Geochim Cosmochim Acta $\mathbf{3 6}$ $537-554$.

Sarin M M, Krishnaswamy S, Dilli K, Somayajulu B L K and Moore W S 1989 Major ion chemistry of GangaBrahmaputra river system: Weathering processes and fluxes of the Bay of Bengal; Geochim Cosmochim Acta $\mathbf{5 3}$ 997-1009.

Sarin M M, Krishnaswamy S, Trivedi J R and Sharma K K 1992 Major ion chemistry of the Ganga source waters: Weathering in the high altitude Himalaya; Proc. Indian Acad. Sci. (Earth Planet. Sci.) 101(1) 89-98.

Scaillet B, France-Lonard C and Le Fort P 1990 BhagirathiGangotri plutons (Garhwal, India): Petrological and geochemical evidence for fractionation processes in a high Himalayan leucogranite; J. Volcanol. Geotherm. Res. 44 $163-188$.

Searle M P, Noble S R, Hurford A J and Rex D C 1999 Age of crustal melting, emplacement and exhumation history of the Shivling leucogranite, Garhwal Himalaya; Geol. Mag. $136513-525$.

Sharma P 2007 Mass balance and chemical characteristics of Chhota Shigri Glacier-B, Lahaul-Spiti Valley, Himachal 
Pradesh; Ph.D. Thesis, Jawaharlal Nehru University, New Delhi, 169p.

Sharp M J 1991 Hydrological inferences from meltwater quality data: The unfulfilled potential; Proc. $\mathrm{BHS} 3^{\text {rd }} \mathrm{Na-}$ tional Hydrological Symposium, Southhampton, 5.1-5.8.

Singh A K and Hasnain S I 1998 Major ion chemistry and weathering control in a high altitude basin: Alaknanda river, Garhwal Himalaya, India; Hydrol. Sci. 43(6) 825-843.

Singh A K and Hasnain S I 2002 Aspects of weathering and solute acquisition processes controlling chemistry of sub-alpine proglacial streams of Garhwal Himalaya, India; Hydrol. Proc. 16 835-849.

Singh A K, Mondal G C, Singh P K, Singh S, Singh T B and Tewary B K 2005 Hydrochemistry of reservoirs of Damodar river basin, India: Weathering processes and water quality assessment; Environ. Geol. 48 1014-1028.

Singh A K, Pandey S K and Panda S 1998 Dissolved and sediment load characteristics of Kafni glacier meltwater, Pindar valley, Kumaon Himalaya; J. Geol. Soc. India 52 305-312.

Singh P, Kumar A and Kishore N 2011 Meltwater storage and delaying characteristics of Gangotri glacier (Indian Himalayas) during ablation season; Hydrol. Proc. 25 159-166.

Srivastava D, Absar A, Sangewar C V, Pandey S N, Oberoi L K and Siddiqui M A 2004 Chemical signatures of lithology on Gangotri glacier meltwater and GaumukhTehri dam section of Bhagirathi River, Proc. Workshop on Gangotri Glacier; Geol. Surv. India Spec. Publ. 80 $223-226$.
Stallard R F 1980 Major elements geochemistry of the Amazon River system; PhD Thesis, WHOI-80-29, MIT/ Woods Hole Oceanographic Institution, USA.

Stumm W and Morgan J J 1970 Aquatic Chemistry (New York: Wiley Interscience).

Thomas A G and Raiswell R 1984 Solute acquisition in glacial meltwaters, II Glacier d'Argentiere (French Alps): Bulk meltwaters with open system characteristics; J. Glaciol. 30(104) 44-48.

Tranter M, Brown G H, Raiswell R, Sharp M J and Gurnell A M 1993 A conceptual model of solute acquisition by Alpine glacial meltwaters; J. Glaciol. 39 573-581.

Tranter M and Raiswell R 1991 The composition of the englacial and subglacial components in bulk meltwaters draining the Gornergletscher, Switzerland; J. Glaciol. 37(125) 59-66.

Trivedi S, Gopal K and Singh J 2010 Hydrogeochemical attributes of the meltwater emerging from Gangotri glacier, Uttaranchal; J. Geol. Soc. India 76 105-110.

Trudgill S T 1986 Solute Processes (Chichester: John Wiley \& Sons Ltd.), 509p.

Valdiya K S 1998 Dynamic of Himalaya (Hyderabad: Universities Press), 178p.

Wadham J L, Hodson A J, Tranter M and Dowdeswell J A 1998 The hydrochemistry of meltwater draining a polythermal-based, high Arctic glacier, south Svalbard. I: The ablation season; Hydrol. Proc. 12 1825-1849.

Yin A 2006 Cenozoic tectonic evolution of the Himalayan orogen as constrained by along-strike variation of structural geometry, exhumation history, and foreland sedimentation; Earth Sci. Rev. 76 1-131. 